\title{
Társas kapcsolatok és mentális egészség szegregált településrészeken
}

\author{
Social Relations and Mental Health in Segregated Settlement Parts
}

\author{
Szerzők: $\quad$ Huszti Éva $\triangle$, Ember Zsolt ${ }^{\mathrm{b}}$ \\ a: Debreceni Egyetem Egészségügyi Kar, b: Semmelweis Egyetem Mentális \\ Egészségtudományok Doktori Iskola
}

Beküldve: $\quad$ 2019. 09. 13.

doi: $\quad$ 10.24365/ef.v60i5.518

\begin{abstract}
Összefoglaló:
Bevezetés: A társas kapcsolatok alapvető hatással vannak az emberek általános jóllétére, mentális egészségére. A hiányos társas kapcsolatrendszer diszfunkciókhoz vezethet az egyén életében és mentális problémákat okozhat. A tanulmány célja, hogy ezt az állitást hátrányos településrészeken élők esetén vizsgálja és az itt élő emberek kapcsolathálózatával és mentális egészségével foglalkozzon. Az itt élők sokszor területileg is kirekesztve élnek, többszörösen depriváltak, általában a legszegényebb, legalacsonyabb iskolai végzettségú és legmagasabb munkanélküliségi rátával jellemezhető csoporthoz tartoznak, ami gyakran vezethet esetükben a többségi populációval való kapcsolatok beszűküléséhez, mely által a sikeres makrotársadalmi integráció, és így a társadalmi mobilitás is lehetetlenné válik számukra. Ez nagyfokú kilátástalansághoz vezet körükben, ami természetesen szintén kihat a mentális egészségükre.
\end{abstract}

Módszertan: A tanulmány az ország észak-keleti részén fekvő megyei jogú város (Nyíregyháza) két, térben elkülönülő szegregátumában élők társas kapcsolatait és mentális egészségét mutatja be. Alapját egy 2019 tavaszán végzett kérdőíves adatfelvételből származó adatbázis nyújtja. A kutatás keretében a két lakótelepen összesen 271 háztartás megkérdezésére került sor.

Eredmények: Az adatok alapján megállapíthatjuk, hogy a két szegregátumban élők társas kapcsolathálózatának kiterjedtsége jelentősen eltér mind a városi, mind az országos adatoktól: kevesebb bizalmasuk, barátjuk van és eltér az általuk elérhető gyenge kapcsolatok struktúrája is. Eltérés figyelhető meg a két lakótelep között is a network mutatókat illetően: a nagyobb lakótelepen élők beszúkültebb kapcsolatrendszerrel bírnak, kevesebb a bizalmasuk, és a baráti kapcsolataik száma is. A mentális egészséggel kapcsolatban elmondható, hogy a vizsgált populáció mind az általános lelkiállapot, mind pedig a vitalitás szempontjából rosszabb helyzetben van, mint a város lakosai: nagyobb arányban érinti az itt élőket az állandóan vagy gyakran fennálló negatív lelkiállapot és ritkább körükben a gyakori pozitív pszichés jóllét, vitalitás.

Következtetések: A két lakótelepen élők mentális egészségi állapotában különbségek figyelhetők meg: a nagyobb telepen élőkre jellemző, hogy a városiakhoz és a másik telephez képest nagyobb azok aránya, akik gyakoribb letörtség- és kimerültségérzetről számoltak be. Másrészt, nagyobb az aránya azoknak, akik gyakran érzik azt, hogy tele vannak energiával. A kisebb lakótelepen élő emberek mentális egészségére jellemző, hogy - a városi adatokhoz és a másik lakótelephez viszonyítva is - körükben magasabb azok aránya, akik általában és gyakran érzik magukat nagyon idegesnek. A gyakori kimerültség érzete viszont - közelítve a városi értékhez - ritkábban érinti az itt élőket, mint a másik lakótelepen élőket. A társas kapcsolatok közül a barátok száma és a vizsgált populáció mentális egészsége között van kimutatható és jelentős kapcsolat: a sok barát hozzájárul a pozitív mentális állapot bizonyos dimenzióihoz.

Kulcsszavak: társas kapcsolatok; mentális egészség; szegregátum; bizalmasok; barátok 


\section{Summary:}

Introduction: Social relationships have a basic effect on the general well-being and mental health of people. Insufficient social connections can lead to dysfunctions in the life of the person and it can cause mental disorders. The aim of the paper is to study this statement in case of people living in disadvantaged areas and address their social network and mental health. People living in these areas are often geographically segregated also; they are multiply deprived, being generally the poorest and the least educated group, with the highest unemployment rate. These situations can often lead to the narrowing of their relations to the majority population, making successful social integration and social mobility impossible for them. This can lead to a high degree of hopelessness among them, which can also affect their mental health status.

Methods: The study introduces the social network and mental health status of people who are living in two, geographically segregated areas of a county town (Nyíregyháza), in the NorthEast of Hungary. The database comes from a questionnaire-based research fulfilled in the spring of 2019. In the research there were 271 households asked from two blocks of flats.

Results: Based on our data, we can conclude that the extent of social networks of people living here is significantly different from town-level and country-level data: they have less confidants, friends and the structure of their weak ties is also different. Differences can be observed between the two blocks of flats as well in terms of the network indicators: people living in the bigger block of flats have a narrower social network, and less confidants and friends. In connection with mental health status we can say, that the studied population's situation is worse in terms of general mood and the level of vitality than it is the case with the whole population of the same city. A higher rate of those living here is affected by constant or regular negative mood. At the same time, the positive mental well-being and the feeling of vitality are less common among them.

Conclusions: There are differences between the mental health status of people living in the two segregated block of flats: on the one hand, there is a higher rate of the more frequent feeling of depression and exhaustion among people living in the bigger block of flats. On the other hand, there is a higher rate of those people who feel lots of energy. Regarding the mental health status of people living in the smallest block of flats there is a high rate of them who feel themselves nervous in general and frequent. While the frequent exhaustion feeling is not so high among them compared to people living in the other block of flats. From among the different types of social relationships, the number of friends and the mental health of the studied population show a significant relationship: the higher number of friends contributes to certain dimensions of the positive mental health status.

Keywords: social networks; mental health; deprived area; confidants; friends

\section{BEVEZETÉS}

A hetvenes évek közepétől, az úgynevezett Lalondejelentés megjelenése óta evidencia, hogy az egyén egészségi állapotát - eltérő mértékben és súllyal, de alapvetően négy tényező determinálja: a genetika, az életmód, a környezet és az egészségügyi ellátás, melyek közül az életmód a leghangsúlyosabb. ${ }^{1}$ Az egyén mentális állapota is több tényezővel áll kapcsolatban, úgymint a testi és fizikai egészségi állapottal, a társadalmi státusszal, ezzel együtt az iskolai végzettséggel, valamint a munkaerőpiaci és jövedelmi helyzettel. Általánosságban elmondható, hogy a jól kvalifikált egyének gyakrabban érzik magukat boldognak, kiegyensúlyozottabbnak, életerősnek, kevésbé gyakori körükben a kimerültség, fáradtság, idegesség. ${ }^{2}$ Témánk szempontjából fontos hangsúlyozni, hogy az egyén mentális állapota nagymértékben függ az egyén társas támogatottságától is: például, a sok baráttal rendelkezők kedvezőbb mentális egészségnek örvendhetnek. ${ }^{2}$

Jelen tanulmány az ország keleti részén elhelyezkedő megyei jogú város, Nyíregyháza két, sok szempontból hátrányos helyzetű lakótelepén végzett 
kutatás adataira épül, és azt vizsgálja, hogy van-e kapcsolat a szegregált településrészeken élő emberek társas kapcsolatrendszere és mentális egészsége között.

Elöljáróban talán érdemes néhány szót szólni a két vizsgált lakótelep főbb sajátosságairól, hiszen ezek a jellemzők alapvetően befolyásolnak bizonyos társadalmi jelenségeket, előre jeleznek társadalmi problémákat, melyek önmagukban is hatással vannak a mentális egészségi állapotra. A város Integrált Települési Stratégiája részeként elkészült Antiszegregációs Program szerint a két településrészt a vonatkozó jogszabály szerint szegregátumnak tekinthetjük. A szegregációs mutatót a 2011-es népszámlálási adatokból állították elő. ${ }^{3}$ Ez alapján a városban három szegregátumot azonosítottak, ezek közül kettővel foglalkozunk a tanulmányban.

Mindkét lakótelep a város egy-egy, egymástól távolabb eső külterületén helyezkedik el. A nagyobb, több lakost számláló lakótelep, a Huszár lakótelep, vagy ahogyan régebben hívták a „Guszev”, a város délnyugati részén, míg a kisebb, kevesebb lakost számláló lakótelep, az Orosi úti vagy Keleti lakótelep, a város keleti részén helyezkedik el. A Huszár lakótelep az ötvenes évek közepéig a Magyar Honvédség tulajdonában lévő, kertvárosi jellegű, a katonai és hivatali elit lakóhelye volt. Jelenleg alacsony bérleti díjú, komfortnélküli, félkomfortos vagy komfortos önkormányzati tulajdonú bérlakások állnak itt, elsősorban roma származású bérlőkkel. A lakótelepet a vasút tulajdonképpen elválasztja a város többi részétől, még a közeli és modernebb lakóteleptől is. Az itt élők zöme alacsony iskolai végzettséggel rendelkezik, mely meghatározza munkaerőpiaci helyzetüket is. A lakótelepen múködik bölcsőde, óvoda, általános iskola, aktívan jelen van a védőnői és a családgondozói ellátás is, valamint működik idősek számára nappali ellátást nyújtó intézmény. A Keleti lakótelep elhelyezkedését tekintve talán kissé szerencsésebb helyzetben van, kevésbé izolált, könnyebben elérhető innen a város akár gyalogosan vagy kerékpárral, de tömegközlekedéssel is. A közeli, fejlettebb lakótelep is könnyen megközelíthető, ahol a közintézményeket, szolgáltatásokat a Keleti lakótelepen élők is igénybe vehetik. A közelben található szupermarket és egyéb üzlet is. Ezek a jellegzetességek kevésbé zárják be az itt élőket a telepi mindennapokba. A „külvilághoz”, a város többi részéhez, intézményekhez, szolgáltatásokhoz való viszony mellett azonban fontos hangsúlyozni, hogy a lakótelepen a lakóingatlanok komfort nélküli, kis alapterületű, alacsony rezsijű, korábban „szebb napokat is látott” önkormányzati bérlakások. Az itt élők iskolázottsága és gazdasági aktivitása hasonló a másik lakótelepen élőkéhöz. ${ }^{4}$

A lakótelepeken végzett korábbi kérdőíves és interjús adatfelvételek említései alapján mindkét lakótelep esetén beszélhetünk az ún. „address discrimination" jelenségről, azaz arról, hogy az itt élők munkavállalási lehetőségeit, különböző szolgáltatásokhoz való hozzáférési esélyeit jelentősen befolyásolja lakcímük: a telephez tartozó utcák, mint lakcím említése során sok esetben kerülnek hátrányos helyzetbe az itt élők. A fenti jelenségek kettős kockázatot („double jeopardy”) jelentenek egyszerre: 1) maga az egyén hátrányos helyzetben van (alacsony iskolázottság, kedvezőtlen munkaerőpiaci helyzet, stb.), ugyanakkor 2) maga a lakótelep, a lakókörnyezet tovább rontja a helyzetet. Mindez hatással van az egészségi állapotra. ${ }^{5}$

1999-ben Macintrye összeállított egy listát arról, hogy melyek azok a lokális társadalmi és fizikai tényezők, melyek hatással lehetnek az egyén egészségi állapotára. ${ }^{6}$ A lista többek között tartalmazza a társas kapcsolathálózat és a társadalmi kohézió meghatározó szerepét is.

$\mathrm{Az}$ Európai Lakossági Egészségfelmérés (ELEF) vonatkozó vizsgálatai azt mutatják, hogy a társas támogatottság hatással van az egészségre, az életmódra és a mentális állapotra is. A 2014-es hazai adatok alapján megállapították, hogy az erős társas kapcsolatokkal rendelkezők általában ritkán mutatnak depresszív tüneteket, míg a gyenge társas támogatottságú egyének több mint fele (55\%) depresszív tüneteket mutat. ${ }^{7}$

Mindezek alapján célunk, hogy a rendelkezésünkre álló adatok alapján bemutassuk a két lakótelepen élő népesség társas kapcsolathálózatának főbb jellegzetességeit, majd kapcsolatot keressünk a személyes kapcsolathálózat összetétele és a mentális egészség között.

Vizsgálati kérdésünk tehát a következő: van-e kapcsolat a szegregált településrészeken élők társas kapcsolathálózatának összetétele, mintázata és az egyének mentális egészsége között? Kimutatható-e lényeges eltérés a két lakótelep között a vizsgált dimenziók és összefüggések mentén? 


\section{MÓDSZERTAN}

Jelen tanulmány alapját egy 2019 tavaszán készült kérdőíves adatfelvétel adja. A kutatás keretében 271 olyan háztartás került lekérdezésre, melyek Nyíregyháza Megyei Jogú Város szegregált településrészein helyezkednek el, földrajzilag elkülönülve egymástól és némiképp a város központi részeitől is. A kutatás során alkalmazott kérdőív a két lakótelepen élő népesség lakhatási viszonyait, egészségi állapotát és más, az életkörülményeikre vonatkozó kérdéseket vizsgált több dimenzió mentén. Emellett alkalmunk nyílt több kérdés segítségével is vizsgálni a társas kapcsolatrendszert.

A felmérés során a két telepen összesen 271 háztartást (a háztartások nagysága alapján becsülve 1089 személyt) értek el a kérdezőbiztosok a városi lakáskezelő vállalat által a kutatás rendelkezésére bocsájtott címlista alapján. A nyilvántartások szerint a két lakótelepen összesen 394 lakás van (Huszár lakótelep: 263, Keleti lakótelep: 131), ahol összesen 1374 fő lakik (Huszár lakótelep: 849, Keleti lakótelep: $525)^{3}$. Ezek alapján a lekérdezési, elérési arány a lakásokra vetítve meglehetősen magas, 69\%-os volt. [1. táblázat]

A vizsgált minta megoszlása nemek szerint nem mutat szignifikáns eltérést a két minta között és általában elmondható, hogy több nő került a válaszadók közé (a válaszadók 70\%-a nő), mely abból adódhat, hogy a kérdezés idején többnyire őket lehetett elérni, és általában a nők azok, akik a háztartással kapcsolatos kérdésekben jártasabbak.

1. táblázat: A minta megoszlása a két telepen (fö)

\begin{tabular}{|c|c|c|c|}
\hline & Huszár lakótelep & Keleti lakótelep & Összesen \\
\hline Háztartások száma & 201 & 70 & 271 \\
\hline Személyek száma & 764 & 325 & 1089 \\
\hline
\end{tabular}

Forrás 8

A minta átlagéletkora 43,5 év, a két minta nem tér el egymástól e tekintetben. Az iskolai végzettséggel kapcsolatban elmondható, hogy kiugróan magas az általános iskolai végzettséggel rendelkezők aránya, felsőfokú végzettség csupán egyetlen egy főnél jelent meg. A középfokú végzettségűek a Huszár lakótelepen 24,5\%-os, a Keleti lakótelepen pedig 17\%-os arányban voltak jelen. A kérdezettek aktuális gazdasági aktivitása alapján a kérdezés idején a válaszadók fele dolgozott (alkalmazottként, vállalkozóként, alkalmi munkában, közmunkában), fele nem. Az elmúlt 12 hónap foglalkoztatottságát tekintve a kérdezettek 73\%-a volt foglalkoztatva (Huszár lakótelep 75\%, Keleti lakótelep 66\%). A családi állapot szerint a mintába kerülők leggyakrabban nőtlenek, hajadonok, akik élettárssal élnek, de viszonylag magas az élettárs nélküli nőtlenek, hajadonok aránya is. A válaszolók valamivel több, mint ötöde (22\%) házas, házastárssal él. A válaszadók 41\%-a vallotta magát romának/cigánynak elsősorban', de a két telep között jelentős eltérés látható: a Huszár lakótelepen élő válaszadók alacsonyabb arányban vallották magukat romának/cigánynak, mint a Keleti lakótelepen élők. [2. táblázat]

A tanulmány során vizsgált dimenziók: társas kapcsolatok, ezen belül a bizalmasok, barátok megléte, illetve a gyenge kapcsolatokkal való rendelkezés, továbbá a kérdezettek mentális állapota. A gyenge kapcsolatok elsődleges funkciója a társadalmi távolságok áthidalása, a közvetítés, illetve információcsere. Hidat képeznek az erős kapcsolatokon keresztül nem elérhető társadalmi csoportokhoz, így az egyén makrotársadalmi integrációját segítik elö. $^{9}$

A 2. táblázatban látható, hogy a bizalmasok száma eltérő a két telepen: a Keleti lakótelepen élő válaszadók több bizalmast neveztek meg a kérdés sii során (az eltérés szignifikáns $p=0,000$ ), és a 2,1-es átlaggal

\footnotetext{
'A kérdés így hangzott: „Az országban és a városban is az emberek sokféle nemzetiséghez vagy etnikumhoz tartoznak. Ön milyen nemzetiségűnek tarja magát elsősorban?"

ii „A legtöbb ember egy-egy fontos dolgot időnként megbeszél másokkal. Ha mondjuk az elmúlt egy évre gondol: kik azok az emberek, akikkel Ön a fontosabb dolgait, problémáit megbeszélte (például, személyes problémák, családi ügyek, munkával kapcsolatos dolgok, stb.)”
} 
az országos átlaghoz közelítenek $(2,19) .{ }^{10} \mathrm{~A}$ bizalmasok összetételében is különbséget figyelhettünk meg a két telepen: a Keleti lakótelepen élők bizalmasai között sokkal magasabb azoknak az aránya, akik nem a telepen, hanem a város távolabbi részein élnek (a bizalmasok 21\%-a él a város távolabbi részein, nem a telep közelében a Keleti lakótelepiek esetén és csupán 9\%-a a Huszár lakótelepen élőknél). Ezek a kapcsolatok a társadalmi integráció miatt lehetnek kulcsfontosságúak.

A barátok számát tekintve is jelentős eltérés figyelhető meg a két telep között: a Keleti lakótelepen élők átlagosan lényegesen több barátot jelöltek meg a kérdésiii mentén. Összességében elmondható, hogy a két lakótelepen átlagosan több baráttal $(4,8)$ rendelkeznek a megkérdezettek, mint a városi, illetve mint az országos átlag (2018-ban 5,1 ill. 2017-ben 2,1). ${ }^{4}$ Ez azonban nem tekinthető különösnek, hiszen korábbi vonatkozó kutatások is azt mutatták, hogy a roma embereknek lényegesen több barátjuk van átlagosan, melynek oka lehet, hogy másképpen értelmezik a barátság szót. ${ }^{11}$

Fontos hangsúlyozni a barátokkal nem rendelkezők kimagasló arányát: összességében a válaszadók 48\%-a nem rendelkezik egy baráttal sem, ami lényegesen több mint az országosan mért 24\%, illetve a városban mért $11 \%{ }^{4} \mathrm{~A}$ két telep között itt is van különbség: a Huszár lakótelepen 49\%, a Keletin pedig 44\% mondta azt, hogy egyetlen barátja sincs. ${ }^{4}$ A gyenge kapcsolatokat egy harminc foglalkozásból álló listán mértük, melyek kapcsán a válaszadónak jeleznie kellett, hogy ismer-e olyan embert, aki az adott foglalkozást képviseli. A válaszadók átlagosan nyolc foglalkozást ismertek a felsoroltak közül, leggyakrabban segédmunkást, gyermekorvost, szakmunkást, szociális munkást. ${ }^{4}$ A két lakótelep között itt is különbséget figyelhetünk meg: a Huszár lakótelepen élők körében magasabb azok aránya, akik átlag alatti gyenge kötéseket ismernek (57\% vs. 47\%). [3. táblázat]

2. táblázat: A minta megoszlása a fóbb szociodemográfiai változók mentén

\begin{tabular}{|c|c|c|c|}
\hline & Huszár lakótelep & Keleti lakótelep & Összesen \\
\hline $\begin{array}{l}\text { Férfi } \\
\text { Nő }\end{array}$ & $\begin{array}{l}\% \\
30 \\
70\end{array}$ & $\begin{array}{c}\% \\
34 \\
66\end{array}$ & $\begin{array}{l}\% \\
31 \\
69\end{array}$ \\
\hline Kor & 43,6 & 43,1 & 43,5 év \\
\hline $\begin{array}{l}\text { Iskolai végzettség } \\
\text { Max. } 8 \text { általános } \\
\text { Szakmunkásképző, szakképzés érettségi nélkül } \\
\text { Érettségi } \\
\text { Magasabb, mint érettségi }\end{array}$ & $\begin{array}{l}\% \\
73 \\
22 \\
2,5 \\
2,5\end{array}$ & $\begin{array}{l}\% \\
83 \\
17 \\
0 \\
0\end{array}$ & $\begin{array}{l}\% \\
75 \\
21 \\
2 \\
2\end{array}$ \\
\hline $\begin{array}{r}\text { Családi állapot } \\
\qquad \begin{array}{r}\text { Nőtlen/hajadon, nincs élettársa } \\
\text { Nőtlen/hajadon, élettárssal él } \\
\text { Házas, házastárssal él } \\
\text { Házas, de nem házastársával, hanem élettárssal él } \\
\text { Házas, de külön élnek, nincs élettársa } \\
\text { Elvált, nincs élettársa } \\
\text { Elvált, van élettársa } \\
\text { Özvegy, nincs élettársa } \\
\text { Özvegy, van élettársa }\end{array}\end{array}$ & $\begin{array}{l}\% \\
24 \\
27 \\
22 \\
3 \\
1 \\
7 \\
4 \\
11 \\
1\end{array}$ & $\begin{array}{c}\% \\
24 \\
40 \\
21 \\
1,5 \\
0 \\
4,5 \\
1,5 \\
7,5 \\
0\end{array}$ & $\begin{array}{c}\% \\
24 \\
30,5 \\
22 \\
3 \\
0,5 \\
6 \\
3 \\
10 \\
1\end{array}$ \\
\hline
\end{tabular}

\footnotetext{
iii „Hány barátja van Önnek?”
} 


\begin{tabular}{|c|c|c|c|}
\hline \multicolumn{4}{|l|}{ Gazdasági aktivitás } \\
\hline Jelenleg dolgozik & $53 \%$ & $49 \%$ & $52 \%$ \\
\hline Jelenleg nem dolgozik & $47 \%$ & $51 \%$ & $48 \%$ \\
\hline \multicolumn{4}{|l|}{ Milyen nemzetiségúnek vallja magát elsősorban? } \\
\hline Roma & $35 \%$ & $57 \%$ & $41 \%$ \\
\hline Nem roma & $65 \%$ & $43 \%$ & $59 \%$ \\
\hline
\end{tabular}

Forrás ${ }^{8}$

A 3. táblázat második részében láthatjuk a mentális egészségre vonatkozó kérdésekre adott válaszok átlagait. Ezek alapján elmondható, hogy általában közepesre minősítették a válaszadók állapotukat a kérdések mentén, azaz időnként előfordult velük, hogy az elmúlt négy hétben fáradtak $(2,4)$, kimerültek $(2,7)$, nagyon idegesek $(2,8)$ és szomorúak, kedvetlenek $(3,2)$, illetve letörtek $(3,45)$ voltak. (Az alacsonyabb átlag ezeknél a kérdéseknél a kedvezőtlenebb állapotot jelzi.) Ugyanakkor hasonló rendszerességgel, időnként azt is érezték, hogy boldogok $(2,4)$, nyugodtak, békések $(2,4)$, tele vannak életerővel $(2,7)$, tele vannak energiával $(2,8)$. (Az alacsonyabb átlag ezeknél a kérdéseknél a kedvezőbb állapotot jelzi.) A két telep között szinte egyáltalán nincs különbség a mentális egészség mutatóinak átlaga között.

3. táblázat: A minta megoszlása a vizsgált változók alapján

\begin{tabular}{|c|c|c|c|}
\hline & Huszár lakótelep & Keleti lakótelep & Összesen \\
\hline \multicolumn{4}{|c|}{ Network változók } \\
\hline $\begin{array}{l}\text { Átlag } \\
\text { Min. } \\
\text { Max. } \\
\text { Szórás }\end{array}$ & $\begin{array}{c}1,3 \\
0 \\
10 \\
1,06\end{array}$ & $\begin{array}{c}2,1 \\
0 \\
6 \\
1,54\end{array}$ & $\begin{array}{c}1,5 \\
0 \\
5 \\
1,31\end{array}$ \\
\hline $\begin{array}{l}\text { Átlag } \\
\text { Min. } \\
\text { Max. } \\
\text { Szórás }\end{array}$ & $\begin{array}{c}3,4 \\
0 \\
98 \\
13,106\end{array}$ & $\begin{array}{c}9,4 \\
0 \\
98 \\
20,394\end{array}$ & $\begin{array}{c}4,8 \\
0 \\
98 \\
15,354\end{array}$ \\
\hline $\begin{aligned} & \text { Gyenge kapcsolatok aránya (átlag 8) } \\
& \text { Átlag alatti } \\
& \text { Átlag feletti }\end{aligned}$ & $\begin{array}{l}57 \% \\
43 \%\end{array}$ & $\begin{array}{l}47 \% \\
53 \%\end{array}$ & $\begin{array}{l}55 \% \\
45 \%\end{array}$ \\
\hline \multicolumn{4}{|c|}{$\begin{array}{l}\text { Mentális egészség változók - átlag } \\
\text { Az elmúlt } 4 \text { hétben milyen gyakran érezte... iv12 (1=általában, 2= gyakran, 3=időnként, 4=ritkán, 5=soha) }\end{array}$} \\
\hline azt, hogy tele van életerővel? (+) & 2,7 & 2,8 & 2,7 \\
\hline azt, hogy nagyon ideges? (-) & 2,7 & 2,8 & 2,8 \\
\hline $\begin{array}{l}\text { azt, hogy annyira letört, hogy semmi sem tudja } \\
\text { felvidítani? (-) }\end{array}$ & 3,45 & 3,45 & 3,45 \\
\hline nyugodtnak és békésnek magát? (+) & 2,4 & 2,4 & 2,4 \\
\hline
\end{tabular}

\footnotetext{
iv A kérdéssor az SF-36 egészséggel kapcsolatos életminőséget mérő kérdőiv (Short Form Health Survey) egy része, amely a mentális egészséget vizsgálja a kilenc kérdés mentén. Ennek egy része az elmúlt hónapra vonatkoztatott általános lelkiállapotra, másik része a pszichés jóllétre, vitalitásra vonatkozóan tartalmaz kérdéseket. ${ }^{12}$
} 


\begin{tabular}{|l|l|l|l|}
\hline azt, hogy tele van energiával? (+) & 2,8 & 2,9 & 2,8 \\
\hline szomorúnak és kedvetlennek magát? (-) & 3,2 & 3,3 & 3,2 \\
\hline azt, hogy kimerült? (-) & 2,7 & 2,8 & 2,7 \\
\hline boldognak magát? (+) & 2,3 & 2,4 & 2,4 \\
\hline azt, hogy fáradt? (-) & 2,4 & 2,5 & 2,4 \\
\hline
\end{tabular}

Forrás: saját szerkesztés

\section{EREDMÉNYEK}

\section{Mentális egészség}

Részletesebben megvizsgáltuk a mentális egészséget mérő kérdésekre adott válaszok gyakoriságát, azon belül is azt, hogy a megkérdezettek hány százaléka válaszolt úgy, hogy vele általában vagy gyakran előfordulnak az adott jelenségek. A válaszadók kevesebb, mint fele érezte általában vagy gyakran azt a vizsgálat elötti négy hétben, hogy tele van életerővel (43\%), energiával (39,5\%). Valamivel több, mint fele mondta azt, hogy nyugodt, békés $(54,5 \%)$, illetve boldog volt (57\%). Negyedükre általában vagy gyakran volt jellemző a letörtség (26\%), szomorúság, kedvetlenség (27\%). A vá- laszadók csaknem fele érezte általában vagy gyakran azt, hogy ideges (43\%), kimerült (44\%). 55\%-uk érezte magát általában vagy gyakran fáradtnak. Ha mindezt összevetjük a vonatkozó városi adatokkal, látható, hogy a vizsgált lakótelepeken élőkre magasabb arányban jellemző az, hogy általában vagy gyakran idegesek, letörtek, szomorúak, kimerültek, fáradtak és kevésbé gyakori az, hogy úgy érzik, tele vannak életerővel, energiával, nyugodtak, békések, boldogok. A két lakótelep között vannak eltérések: a Keleti lakótelepen magasabb azok aránya, akik nagyon idegesnek érezték magukat az elmúlt hónapban, míg a Huszár lakótelepiek gyakrabban számoltak be arról, hogy letörtek vagy kimerültek voltak. Azt, hogy tele vannak energiával, a Huszár lakótelepiek gyakrabban érezték, mint a másik lakótelepen élők. (A fenti különbségek nem szignifikánsak.) [4. táblázat]

4. táblázat: Mentális egészség (gyakoriság, \%)

\begin{tabular}{|c|c|c|c|c|}
\hline $\begin{array}{c}\text { Az elmúlt } 4 \text { hétben általában, gyak- } \\
\text { ran érezte... }\end{array}$ & $\begin{array}{l}\text { Nyíregyháza } \\
\text { (2018) }\end{array}$ & $\begin{array}{c}\text { Lakótelepek } \\
\text { együtt } \\
\text { (2019) }\end{array}$ & $\begin{array}{l}\text { Huszár } \\
\text { lakótelep }\end{array}$ & $\begin{array}{c}\text { Keleti } \\
\text { lakótelep }\end{array}$ \\
\hline azt, hogy tele van életerővel? & 57 & 43 & 43 & 43 \\
\hline azt, hogy nagyon ideges? & 32 & 43 & 41 & 48 \\
\hline $\begin{array}{l}\text { azt, hogy annyira letört, hogy semmi } \\
\text { sem tudja felvidítani? }\end{array}$ & 16 & 26 & 27 & 23 \\
\hline nyugodtnak és békésnek magát? & 70 & 54,5 & 54 & 55 \\
\hline azt, hogy tele van energiával? & 55 & 39,5 & 42 & 32 \\
\hline szomorúnak és kedvetlennek magát? & 13 & 27 & 27 & 26 \\
\hline azt, hogy kimerült? & 37 & 44 & 45 & 39 \\
\hline boldognak magát? & 75 & 57 & 58 & 55 \\
\hline azt, hogy fáradt? & 50 & 55 & 55 & 55 \\
\hline
\end{tabular}

Forrás: saját szerkesztés 
Az adatok elemzése során a továbbiakban arra fókuszálunk, hogy a különböző kapcsolathálózati változók és a mentális egészséget mérő változók között megfigyelhető-e összefüggés.

A bizalmasok száma, összetétele és a mentális egészségi állapot mutatói között nem találtunk szignifikáns kapcsolatot, ahogyan a gyenge kapcsolatok száma sem mutatott összefüggést a mentális egészség változóival.
A barátok átlagos száma három általános lelkiállapot mutatóval van szignifikáns kapcsolatban: 1) minél több barátot tudhat maga körül a válaszadó, annál jellemzőbb rá, hogy az elmúlt hetekben gyakran érezte magát nyugodtnak és békésnek, 2) minél több a barát a kapcsolathálózatban, annál ritkábban jellemző a szomorúság és kedvetlenség, 3) a több barát hozzájárul a gyakoribb boldogságérzethez. [5. táblázat]

\section{5. táblázat: Barátok száma és mentális állapot (átlag)}

\begin{tabular}{|l|c|c|c|c|c|}
\hline & $\begin{array}{c}\text { Nincs } \\
\text { barátja }\end{array}$ & $\mathbf{1 - 4}$ barát & $\mathbf{5 - 9}$ barát & $\begin{array}{c}10+ \\
\text { barát }\end{array}$ & Sig. \\
\hline Nyugodtnak és békésnek érezte magát? (+) & 2,52 & 2,42 & 2,1 & 1,6 & 0,003 \\
\hline Szomorúnak és kedvetlennek érezte magát? (-) & 3,06 & 3,16 & 3,8 & 3,7 & 0,047 \\
\hline Boldognak érezte magát? (+) & 2,5 & 2,4 & 2,1 & 1,7 & 0,020 \\
\hline
\end{tabular}

Forrás: saját szerkesztés

6. táblázat: Barátok száma, mentális állapot nemek szerint (átlag)

\begin{tabular}{|c|c|c|c|c|c|c|c|c|}
\hline \multirow{2}{*}{$\begin{array}{c}\text { Az elmúlt } 4 \text { hétben általában, gyakran } \\
\text { érezte... }\end{array}$} & \multicolumn{2}{|c|}{$\begin{array}{c}\text { Nincs } \\
\text { barátja }\end{array}$} & \multicolumn{2}{|c|}{ 1-4 barát } & \multicolumn{2}{|c|}{ 5-9 barát } & \multicolumn{2}{|c|}{ 10+ barát } \\
\hline & férfi & nő & férfi & nő & férfi & nő & férfi & nő \\
\hline azt, hogy tele van életerővel? & 2,75 & 2,9 & 2,9 & 2,5 & 2,7 & 3,5 & 2,9 & 2 \\
\hline azt, hogy nagyon ideges? & 2,75 & 2,8 & 2,3 & 2,9 & 3,2 & 2,5 & 3,1 & 2,65 \\
\hline $\begin{array}{l}\text { azt, hogy annyira letört, hogy semmi } \\
\text { sem tudja felvidítani? }\end{array}$ & 3,2 & 3,5 & 3,1 & 3,5 & 4 & 3,75 & 3,75 & 3,6 \\
\hline nyugodtnak és békésnek magát? & 2,75 & 2,4 & 2,45 & 2,4 & 1,8 & 2,5 & 1,6 & 1,5 \\
\hline azt, hogy tele van energiával? & 3,2 & 2,9 & 2,9 & 2,75 & 2,5 & 3,5 & 2,9 & 2 \\
\hline szomorúnak és kedvetlennek magát? & 2,7 & 3,2 & 2,9 & 3,3 & 3,8 & 3,75 & 3,25 & 3,9 \\
\hline azt, hogy kimerült? & 2,6 & 2,7 & 2,5 & 2,8 & 2,7 & 2,5 & 2,1 & 3 \\
\hline boldognak magát? & 2,9 & 2,4 & 2,5 & 2,4 & 2 & 2,25 & 2,5 & 1,65 \\
\hline azt, hogy fáradt? & 2,1 & 2,3 & 2,2 & 2,7 & 2,8 & 2,5 & 2,25 & 2,35 \\
\hline
\end{tabular}

Forrás: saját szerkesztés

Korcsoportok alapján elmondható, hogy a legfiatalabb megkérdezettek esetén van összefüggés a barátok száma és a nyugodt, békés érzet között: esetükben a barátok népes száma hozzájárul a nyugalomhoz $(p=0,032)$.

A párkapcsolatban élés is szignifikánsan befolyásol néhány mentális tényezőt a barátok számát is tekintve: azokra, akik nem élnek párkapcsolatban, és nincsenek barátaik, jellemző a gyakori szomorúság és kedvetlenség $(p=0,024)$. Minél több a barát, annál ritkább ez az érzet. A párkapcsolattal nem rendelkezők boldogságérzetét jelentősen növeli a barátok száma: minél több barátja van, annál gyakoribb a boldogság $(p=0,046)$. Akik párkapcso- 
latban élnek és sok barátjuk van, gyakrabban voltak nyugodtak és békések a vizsgálat előtti négy hétben $(p=0,021)$.

A mentális egészségre vonatkozó kérdéssor általános lelki állapotra (5 item) illetve pszichés jóllétre, vitalitásra vonatkozó itemeiből (4) külön változókat hoztunk létre. Adataink alapján a barátok száma összefüggést mutatott a mentális egészségre vonatkozó kérdéssor általános lelkiállapotra vonatkozó itemeivel: minél több barátja van, annál gyakoribb a pozitív lelkiállapot $(p=0,014)$.

\section{MEGBESZÉLÉS}

A vizsgált lakótelepeken élők társas kapcsolathálózatának kiterjedtsége eltér az országostól: kevesebb bizalmassal (országos átlag: 2,2 fő - vizsgált lakótelepek átlaga: 1,5 fö), de átlagosan több baráttal rendelkeznek (országos átlag: 2,1 fö - vizsgált lakótelepek átlaga 4,8 fö). ${ }^{10}$ Ezzel együtt az is lényeges, hogy magasabb körükben a baráttal nem rendelkezők aránya. A két vizsgált lakótelep között is lényeges különbségek adódtak: a Keleti lakótelepen élők átlagosan szignifikánsan több bizalmassal és több baráttal bírnak, mint a Huszár lakótelepen élők. ${ }^{4}$

A mentális egészséget vizsgáló kérdések mentén megállapítható, hogy az általános lelki állapot lényegesen rosszabb képet mutat a vizsgált populáció esetén, mint ugyanannak a városnak az általános mutatói, továbbá vitalitás és energia tekintetében lényegesen rosszabb helyzetről számoltak be a vizsgált lakótelepeken élők. Míg például a Nyíregyháza életminősége kutatás 2018-as adatfelvétele idején a válaszadók 57\%-a mondta azt, hogy az elmúlt négy hétben általában gyakran érezte azt, hogy tele van életerővel, addig a két vizsgált lakótelepen élőknél ez csupán 43\% volt. A nyugodt, békés érzet a városlakók 70\%-ára, míg a szegregált településrészeken élők 54,5\%-ára volt jellemző általában vagy gyakran. Azt, hogy nagyon ideges, a szegregátumban élők 43\%-a érezte gyakran a kérdezést megelőző négy hétben, míg a nyíregyházi felnőtt populációnak 32\%-ára volt ez jellemző. A letörtségérzet a szegregátumokban élő felnőttek $26 \%$-ára volt igaz, míg ugyanazon település más részein élőknél ez az arány 16\% volt. A szomorúság, kedvetlenség a lakótelepiek negyedénél (27\%), míg a városlakók 13\%-ánál fordult elő általában vagy gyakran.
A társas kapcsolatok közül a barátok száma mutat összefüggést a vizsgált populáció mentális egészségével: minél több barátja van az egyénnek, annál gyakrabban érzi magát nyugodtnak, békésnek és boldognak és ritkábban szomorúnak és kedvetlennek. A két lakótelepet külön vizsgálva elmondható, hogy a barátok száma a Keleti lakótelepen függ össze azzal, hogy milyen gyakran érzi magát nyugodtnak az egyén (minél több barátja van, annál gyakrabban jellemző ez az állapot), illetve a fáradtsággal. Mindkét telepen szignifikáns kapcsolat van a barátok száma és a boldogság érzete között.

\section{KÖVETKEZTETÉSEK}

A Huszár lakótelepen élők esetében egy, a várostól jobban elkülönített lakókörnyezetről beszélhetünk, aminek eredménye, hogy az ott élők társas hálója is zártabb és kisebb (kevesebb bizalmas, kevesebb barát, kevesebb gyenge kötés). Tulajdonképpen a telepet a város nagyobb részétől elválasztó sorompó egyben „kapcsolati sorompónak” is tekinthető a többségi lakossággal való viszonyrendszerben, ráadásul számos szolgáltatás a lakótelepen belül van, ami fokozza a szeparációt és csökkenti a többségi lakossággal való érintkezés lehetőségét. Mentális egészségükre jellemző, hogy a városiakhoz és a másik telephez képest nagyobb azok aránya, akik gyakoribb letörtség- és kimerültség érzetről számoltak be. Másrészt, elmaradva ugyan a városi gyakoriságtól, de a másik lakótelepen élókhöz képest nagyobb az aránya azoknak, akik gyakran érzik azt, hogy tele vannak energiával. A Keleti lakótelepen élő emberek egy kedvezőbb, integratívabb helyzetben vannak: lakókörnyezetük közelebb van a városközponthoz, így kevésbé elkülönítettek, közösségük nyitottabb. A különböző társadalmi helyszínek közelebb vannak hozzájuk, így a város társadalmi életébe jobban be tudnak kapcsolódni és abban nagyobb mértékben részt tudnak venni. Mentális egészségükre jellemző, hogy - a városi adatokhoz és a másik lakótelephez viszonyítva is körükben magasabb azok aránya, akik általában és gyakran érzik magukat nagyon idegesnek. A gyakori kimerültség érzete viszont - közelítve a városi értékhez - ritkábban érinti az itt élőket, mint a másik lakótelepen élőket. A társas kapcsolatok közül a barátok azok, akiknek száma összefügg a mentális 
egészségi állapottal, azon belül is az általános lelkiállapottal mutat pozitív összefüggést és adataink szerint, noha a Keleti lakótelepen élők körében is magas a baráttal nem rendelkezők aránya (44\% vs. 49\%), átlagosan háromszor több baráttal rendelkeznek, mint a Huszár lakótelepen élők (9 vs. 3).
Itt kell figyelembe venni azt a tényt is, hogy a Keleti lakótelepen élők bizalmasai többnyire a város más részein élő roma emberek, ezért ezek a kapcsolatok valószínűleg jobban szolgálják a társadalmi integráció folyamatát.

\section{HIVATKOZÁSOK}

\footnotetext{
${ }^{1}$ Lalonde M: A New Perspective on the Health of Canadians Minister of Supply and Services, Ottawa 1974

${ }^{2}$ Ambrus Z, Varsányi T: Az egészség és az életmód regionális különbségei. Területi Statisztika 2011 51(3)227-244 (Elérve: 2019.09.12.)

${ }^{3}$ www1 http://varoshaza.nyiregyhaza.hu/lib/rend_terv/its/170426_2014_2020_its_1mod.pdf (Elérve: 2019.09.10.)

${ }^{4}$ Huszti É: Telepi kapcsolatok. Megjelenés alatt

${ }^{5}$ Macintyre SEllaway: A Neighborhoods and Health. An Overview. In: Kawachi I Berkman L F (editor) Neighborhoods and Health. Oxford University Press, Oxford, 2003 pp 20-42.

${ }^{6}$ Macintrye S: Inequalities in health - Geographical inequalities in mortality, morbidity and health related behaviour in England. In: Gordon D, Shaw M, Dorling D, Davey Smith G (eds). Inequalities in Health: The Evidence Presented to the Independent Inquiry into Inequalities in Health. Policy Press, Bristol, 1999 pp. 148-154.

${ }^{7}$ www2 http://www.ksh.hu/docs/hun/xftp/idoszaki/elef/elef2014_osszefoglalo.pdf (Elérve: 2019.09.11.)

${ }^{8}$ Takács P, Huszti É: A nyíregyházi Huszár- és Keleti lakótelepi vizsgálatok - a kutatás módszertana és a minta néhány alapvető jellemzője. Megjelenés alatt.

${ }^{9}$ Dávid B, Huszti É, Lukács Á: A társas kapcsolatok jelentősége a társadalmi integrációban. In. Dr. Kósa Zs. (szerk.): Helyzetkép a magyarországi romákról. Debreceni Egyetemi Kiadó. Debrecen 2016. pp. 67-86.

${ }^{10}$ Albert, F. - Dávid, B: A magyarországi kapcsolathálózati struktúrák jellemzői 2015-ben. Társadalomtudományi Szemle, 2016; 3:22-47. doi: 10.18030/socio.hu.2016.3.22. (Elérve: 2019. 09.11.)

${ }^{11}$ Albert F,, Dávid B. Embert barátjáról. A barátság szociológiája. Századvég, Budapest, 2007. pp. 164-172.

12 Kósa K, Bíró É: A mentális állapot populációs szintű vizsgálatának koncepciói és eszközei. Mentálhigiéné és Pszichoszomatika 2018;19(2): 103-139 doi: 10.1556/0406.19.2018.005 (Elérve: 2019. 09.10.)
} 